\title{
REDESCRIPTION OF CATFISHES AmbLYCEPS ARUNACHALENSIS NATH \& DEY AND AMbLYCEPS APANGI NATH \& DEY (TELEOSTEI: AMBLYCIPITIDAE)
}

\author{
W. Vishwanath ${ }^{1}$ and I. Linthoingambi ${ }^{2}$ \\ Department of Life Sciences, Manipur University, Canchipur, Imphal, Manipur 795003, India \\ Email: ${ }^{1}$ vnath54@yahoo.co.in; ${ }^{2}$ ilinthoi@yahoo.com
}

plus web supplement of 1 page

\begin{abstract}
Amblyceps arunachalensis and $A$. apangi are redescribed. $A$. arunachalensis has been resurrected from synonymy with $A$. mangois. A. arunachalensis markedly differs from A. mangois in general appearance of the body, the caudal fin lobes, eye diameter, caudal peduncle height, interorbital space, and the number of vertebrae. A. arunachalensis differs from $A$. apangi in characteristics relating to the rictal fold, caudal peduncle length, caudal peduncle height, caudal fin, fold on lips, adipose fin, and number of vertebrae.
\end{abstract}

KEYWORDS

Amblycipitidae, Amblyceps apangi, A. arunachalensis, A. mangois, fishes, redescription, revalidation

Abbreviations

ZSI- Zoological Survey of India, Itanagar; NATP- National Agricultural Technology Project; MUMF - Manipur University Museum of Fishes

$\mathrm{Ng}$ (2005) recognized 13 species of the genus Amblyceps Blyth out of which the four species distributed in the GangaBrahmaputra drainage are $A$. apangi Nath \& Dey, A. laticeps McClelland, A. mangois (Hamilton) and A. tenuispinnis Blyth. Genus Amblyceps is characteristic in having: epiphyseal commissure of supraorbital sensory canals immediately anterior to, and not passing through, epiphyseal bar; anterior cranial fontanel narrowing abruptly along its posterior end; fifth ceratobranchial expanding medially at its posterior tip; pinnate-like rays along anterior margins of the several procurrent caudal fin rays immediately anterior to upper and lower outermost branched caudal fin rays; transverse crest along entire posterior margin of roof of supraoccipital and pterotic; lateroposterior process of horizontal lamina of urohyal short or vestigial, shorter than horizontal lamina; upper hypurals fused with compound centrum; anterior nostril situated immediately anterior to base of nasal barbel, and both lips with double folds (Chen \& Lundberg, 1995). It is also characteristic in having a prominent cup-like skin flap above the base of the pectoral spine (Hora, 1933).

Nath \& Dey (1989) described $A$. apangi and $A$. arunachalensis from Dikrong River, Arunachal Pradesh, India. The existence of the two species had attracted less attention till the recent work of $\mathrm{Ng}$ (2005) who treated $A$. apangi, a valid species and $A$. arunachalensis, a synonym of $A$. mangois. As the descriptions of $A$. apangi and $A$. arunachalensis by Nath \& Dey (1989) are inadequate, an attempt has been made in the present study to redescribe the two species based on specimens collected from Arunachal Pradesh, India. A. arunachalensis is resurrected from synonymy with $A$. mangois.

\section{MATERIAL AND Methods}

Measurements were made on left side of the body with dial calipers to the nearest $0.1 \mathrm{~mm}$ using method of $\mathrm{Ng} \& \mathrm{Lim}$ (1995), for head length $\mathrm{Ng} \&$ Kottelat (1998) and for adipose fin base length $\mathrm{Ng} \&$ Kottelat (2000). Counts and measurements were made on the left side of specimens wherever possible. Subunits of the head are presented as proportions of head length (HL). Head length and measurements of body parts are given as proportions of standard length (SL). Specimens were processed for vertebrae counts following Hollister (1934) and counted following Roberts (1989). Fin rays were counted under a PC based binocular stereo-zoom microscope (Olympus Model SZ40) using transmitted light.

Specimens for the study are deposited in Manipur University museum of Fishes (MUMF). Specimens deposited in Department of Zoology, Rajiv Gandhi University and ZSI Arunachal Pradesh was compared.

\section{Amblyceps arunachalensis Nath \& Dey, 1989 \\ (Image $1^{\mathrm{w}}$ )}

\section{Material examined}

3 ex., 15.i.2005, Dikrong River, Doymukh, Arunachal Pradesh, India, coll. Millo Ruja, 68.1-82.7mm SL (MUMF 6401); 11 ex., 8.ix.2004, Dikrong River, Doymukh, Arunachal Pradesh, India, coll. Millo Ruja, India, 72.0-85.5 mm SL (uncatalogued).

\section{Distribution}

India: Arunachal Pradesh (Brahmaputra basin).

\section{Diagnosis}

Jaws with lower longer than upper; rictal fold reduced; head almost round, its maximum width $88.3-89.4 \%$ its length, depth at occiput $70.4-71.4 \%$ its length; eye diameter $7.0-9.0 \%$ HL; interorbital space 44.2-44.4\% HL; gape width 50.4-51.2\% HL; caudal peduncle height 50.5-51.2\% its length; HL 18.5-19.0\% SL; skin tuberculated, pinnate like rays on outer margin of procurrent rays of caudal fin present; caudal fin with upper lobe longer, length of longest ray of lower lobe 75.1-76.0\% length of longest ray of upper lobe; adipose fin widely separated from caudal fin.

\section{Description}

Body long, slender gradually getting compressed

${ }^{w}$ See Images in the websupplement at www.zoosprint.org

Manuscript 1606; (C) ZOO; Date of publication 21 March 2007 Received 31 July 2006; Finally accepted 25 January 2007 
Table 1. Morphometric data of Amblyceps arunachalensis and $A$. apangi

\begin{tabular}{lll}
\hline Characters & A. arunachalensis & A. apangi \\
\hline Percentages standard length & & \\
Head length & $18.5-19.0$ & $21.1-23.0$ \\
Body depth (at dorsal) & $15.0-15.4$ & $13.0-13.7$ \\
Body depth (at anus) & $14.6-14.7$ & $14.2-16.0$ \\
Snout length & $05.5-06.0$ & $08.0-08.3$ \\
Caudal peduncle length & $22.0-22.6$ & $18.4-20.0$ \\
Dorsal fin base & $10.4-11.2$ & $08.0-08.3$ \\
Adipose fin base & $17.2-17.8$ & $13.4-15.0$ \\
Pectoral fin length & $14.4-15.4$ & $12.5-13.3$ \\
Pelvic fin length & $09.7-10.6$ & $10.0-10.2$ \\
Anal fin length & $17.0-18.0$ & $14.0-14.2$ \\
Percentages head length & & \\
Head depth (nape) & $70.4-71.4$ & $43.5-46.2$ \\
Head width (maximum) & $88.3-89.4$ & $69.5-76.5$ \\
Eye diameter & $07.0-09.0$ & $08.0-09.0$ \\
Interorbital space & $44.2-44.4$ & $27.0-30.2$ \\
Gape width & $50.4-51.0$ & $43.5-49.4$ \\
Internarial & $19.1-20.2$ & $17.0-17.6$ \\
Caudal peduncle height \% its length & $50.5-51.2$ & $71.0-73.0$ \\
\hline
\end{tabular}

posteriorly. Head short, almost rounded. Mouth terminal with lower jaw longer than upper. Lips with double folds. Teeth in upper jaw as narrow band with posterior extensions on both sides and separated by a very narrow gap, those in lower jaw in a semicircular band, separated in middle. Prominent fold of skin present posterior to opercular flap. Fleshy rim of posterior naris an incomplete tube with posterior notch while that of the anterior nards a complete tube. Eyes small and subcutaneous.

Barbels: Four pairs, compressed throughout their length, nasal when adpressed extends upto dorsal end of head. Maxillary extends upto middle of pectoral fin base. Outer mandibular beyond posterior end of pectoral fin base. Inner mandibular extends upto isthmus.

Fins: Dorsal fin origin vertically through middle length of pectoral fin bearing I, 6 rays, the spine feeble and hidden beneath skin. Adipose fin at vertical level of anal fin origin, its posterior margin round and widely separated from caudal fin. Pectoral fin with I, 7 rays, spine smooth and comparatively stronger. It extends upto vertically through just behind middle length of dorsal fin base. Pelvic fin origin just beyond vertical level of middle of interdorsal distance, bearing I, 5 rays. Anal fin situated in front of vertical level of adipose fin origin, bearing V, 9 rays. Caudal fin deeply forked, upper lobe longer, two outer most branched rays longest, bearing $6+9$ rays. Length of longest ray of lower lobe 75.1-76.0\% length of longest ray of upper lobe.

Skin on body and head tuberculated. Lateral line absent.

Vertebrae: $21+19$ (40).

Colour. Body grey. Fins plain, tinged grey.

\section{Amblyceps apangi Nath \& Dey, 1989}

(Image $2^{\mathrm{w}}$ )

\section{Material examined}

4 ex., 15.i.2005, Dikrong River, Doymukh, Arunachal Pradesh, India, coll. Millo Ruja, ; 60.0-77.8mm SL (MUMF 6404); 2 ex., 11.iv.2004, Dikhu River, Moalenden Mokokchung, Nagaland, India, coll. Bendangkokpa Jamir, 74.8 \& 81.2mm SL (MUMF 6408); 7 ex., 8.ix.2004, Dikrong River, Doymukh, Arunachal Pradesh, India, coll. Millo Ruja, India, 75.8-92.0mm SL (uncatalogued).

\section{Distribution}

India: Arunachal Pradesh, Nagaland (Brahmaputra basin). $\mathrm{Ng}$ (2005) reported it from West Bengal (Tista drainage).

\section{Diagnosis}

Jaws equal, rictal fold large and very well developed; skin smooth; pinnate-like rays absent; adipose fin not confluent with caudal fin but very closely placed appearing to be confluent; caudal fin truncate; head length 21.1-23.0\% SL; head depth $43.5-50.5 \%$ its length; head width $69.5-76.5 \%$ HL; interorbital space $27.0-30.2 \%$ HL; gape width $43.5-49.4 \%$ HL; caudal peduncle height $71.0-73.0 \%$ its length.

\section{Description}

Body long gradually getting compressed posteriorly. Head narrow and depressed. Mouth terminal with upper jaw longer than lower. Lips thick. Rictal fold very well developed, its upper and lower lobe continue to basal part part of maxillary barbell on each side. Teeth in upper jaw in broad band with posterior extensions on both sides and separated by a very

Table 2. Comparative characters between Amblyceps arunachalensis, A. apangi and A. mangois (Image $\left.3^{w}\right)$.

\begin{tabular}{llll}
\hline Characters & A. arunachalensis & A. mangois & A. apangi \\
\hline Head length\% SL & $18.5-19.6$ & $20.0-21.0$ & $21.1-23.0$ \\
Head depth (nape)\% HL & $70.4-71.5$ & $70.0-74.1$ & $43.5-46.2$ \\
Eye diameter\% HL & $07.0-09.0$ & $10.1-13.0$ & $07.5-09.0$ \\
Interorbital space\% HL & $44.2-44.4$ & $48.2-51.0$ & $27.0-30.2$ \\
Rictal fold & reduced & reduced & large \\
Caudal peduncle length\% SL & $22.0-22.6$ & $17.0-19.5$ & $18.4-20.0$ \\
Caudal peduncle height\% its length & $50.5-51.6$ & $91.4-93.0$ & $71.0-73.0$ \\
Body depth\% SL & $15.0-15.4$ & $17.1-18.3$ & $12.3-13.0$ \\
Caudal fin shapes & upper lobe longer & lobes pointed \& upper & lunate ortruncate \\
& & lobe slightly longer & \\
Skin nature & tuberculated & smooth & smooth \\
Fold on lips & double folds & double folds & single fold \\
Adipose fin confluence with caudal fin & widely separated & widely separated & adipose almost touching caudal \\
Pinnate like rays & present & present & absent \\
Vertebrae & $21+19$ & $20+16$ & $24+19$ \\
Length longest ray lower lobe \% & $75.1-76.0$ & $94.3-95.0$ & - \\
\hline
\end{tabular}


narrow gap, those in lower jaw in a semicircular band, separated in middle. Prominent fold of skin present posterior to opercular flap. Fleshy rim of posterior naris an incomplete tube with posterior notch while that of the anterior naris a complete tube. Eyes small and subcutaneous.

Barbels: Compressed throughout their length. Nasal when adpressed posteriorly reaches to about $3 / 4$ of head length. Maxillary and outer mandibular reaches beyond posterior base of pectoral fin. Inner mandibular reaches about $3 / 4$ of head length.

Fins: Dorsal fin with i-ii, 5-6 rays, origin vertically thoriugh middle length of pectoral fin. Adipose fin origin at vertical level of posterior base of anal fin; its posterior margin tapering almost touching the principal rays of caudal fin. Pectoral fin with I, 6 , i or I, 6 rays. It extends upto vertically through just behind middle length of dorsal fin base. Pelvic fin with I, 5 rays. Anal fin with iii-iv, 7 rays. Caudal fin emarginated, bearing $7+7$ rays, second outer branched rays on upper and lower longest.

Lateral line pores at tip of short tube like structure, pores arranged in pairs, each pair separated by a short gap. Specimen from Dikhu R. Nagaland have more distinct lateral line pores, those from Dikrong River Arunachal Pradesh have thick mucous covering and lateral line less conspicuous.

Vertebrae: $24+19$ (43).

Colour: Body grey. Fins plain.

\section{Discussion}

$\mathrm{Ng}$ (2005) could not examine material referable to $A$. arunachalensis. On the basis of his comparison with the illustrations and data (inadequate as stated above) of Nath \& Dey (1989, 2000), he considered the fish a junior synonym of A. mangois. The present examination of specimens from Arunachal differs from $A$. mangois in smaller eyes, narrower interorbital space, longer and slender caudal peduncle, slender body and more number of post anal and total vertebrae, longer upper lobe of caudal fin (Table 1). Thus A. arunachalensis is treated here as valid species.

While describing $A$. apangi, Nath \& Dey (1989) distinguished it from $A$. mangois based only on the presence of lateral line, longer maxillary barbells and from $A$. arunachalensis in its subcylindrical body, longer adipose fin and in its truncate caudal fin. $\mathrm{Ng}$ (2005) showed its similarity with $A$. murraystuartii Chaudhuri of Irrawady basin in their truncate caudal fin, but separated in having longer head, more vertebrae and colour of body. Detailed examination of $A$. apangi from Dikrong river, Arunachal Pradesh clearly shows its difference from $A$. mangois and $A$. arunachalensis in depressed head and body, larger rictal folds, intermediate caudal peduncle height and smooth skin (Table 2). A. apangi is also distinct in its absence of pinnate like rays.

According to Chen \& Lundberg (1995), pinnate-like rays are present along anterior margins of several procurrent caudal fin rays immediately anterior to upper and lower outermost branched caudal fin rays. According to $\mathrm{Ng} \&$ Kottelat (2000) pinnate-like rays are present on median caudal fin rays. We have not observed the same on the median caudal fin rays but these rays are found on anterior margins of several procurrent rays in $A$. mangois and $A$. arunachalensis. The same character is however lacking totally in A. apangi. $\mathrm{Ng} \&$ Kottelat (2000) and $\mathrm{Ng}$ (2001) reported that the character is pronounced in the species of Indian region.

\section{Comparative material}

Amblyceps mangois: MUMF 4154 \& 4155, 2 exs., 42.5-50.0mm SL, Jiri R., Jiri, Manipur-Assam border. - uncat. 6 exs., 35.648.6mm SL, Barak R., Silchar (all Brahmaputra basins).

\section{REFERENCES}

Chen, X. \& J.G. Lundberg (1995). Xiurenbagrus, a new genus of amblycipitid catfishes (Teleostei: Siluriformes), and phylogenetic relationships among the genera of Amblycipitidae. Copeia 4: 780-800. Hollister, G. (1934). Clearing and dyeing fishes for bone study. Zoologica 12: 89-101.

Hora, S.L. (1933). Siluroid fishes of India, Burma and Ceylon. 1. Loachlike fishes of the genus Amblyceps Blyth. Records of Indian Museum 35: 607-621.

Jayaram, K.C. (2006). Catfishes of India. Narendra Publishing House, New Delhi, xxii+383pp.

Nath, P. \& S.C. Dey (1989). Two new species of the genus Amblyceps Blyth from Arunachal Pradesh, India. Journal of Assam Science 32(1): 16 .

Ng, H.H. (2001). Amblyceps macropterus, a new species of amblycipitid catfish (Osteichthys: Amblycipitidae) from Pakistan. Ichthyological Explorations of Freshwaters 12(3): 201-204.

$\mathrm{Ng}$, H.H. (2005). Amblyceps carinatum, a new species of hillstream catfish from Myanmar (Teleostei: Amblycipitidae). Raffles Bulletin of Zoology 53(2): 243-249.

Ng, H.H. \& K.P. Lim (1995). A revision of the South-east Asian catfish genus Parakysis (Teleostei: Akysidae), with descriptions of two new species. Ichthyological Explorations of Freshwaters 6: 255-266.

Ng, H.H. \& M. Kottelat (1998). The catfish genus Akysis Bleeker (Teleostei: Akysidae) in Indochina, with descriptions of six new species. Journal of the Natural History Society 32: 1057-1097.

Ng, H.H. \& M. Kottelat (2000). A review of the genus Amblyceps (Osteichthyes: Amblycipitidae) in Indochina, with descriptions of five new species. Ichthyological Explorations of Freshwaters 14(4): 335-348.

Roberts, T.R. (1989). The freshwater fishes of Western Borneo (Kalimantan, Barat, Indonesia). Memoris of California Academy of Science 14: 210 .

\section{ACKnowledgement}

Our thanks are due to Prof. S.C. Dey of Gauhati University for literature, ZSI Arunachal Pradesh for access to the types and other collections of A. arunachalensis and A. apangi, Dr. D.N. Das and Millo Ruja of Rajiv Gandhi University, Arunachal Pradesh and Bendangkokpa Jamir, Nagaland University, for their generous helps.

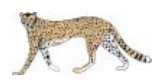

